Ecologist Thomas Eisner $\alpha$ is a photographer as well as a researcher. But the effects of

Farkinson's disease haveled him to explore a new way to capture images, using a colour photocopier. Eisner lays objects such as flowers and shells (as shown here) on the photocopier stage, covered with a black cloth - ideal for anyone with limited mobility, he suggests.

\section{ON THE RECORD}

\section{"Science should claw back its nineteenth- century glamour."}

Columnist Simon Jenkins argues on The Guardian's Comment is Free website that specialist science education is not for the masses.

\section{(Glow depressing to see} ignorance championed in this way."

Response to Jenkins's articlefrom an anomymous poster.

\section{SCORECARD}

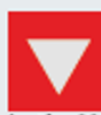

\section{Mushrooms}

After spinach and then lettuce were withdrawn in the United States owing to fear of bacterial contamination, one online betting site has made mushrooms the favourite to be the next foods tuff to be recalled, at $6 / 1$.

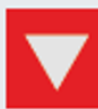

\section{Cloned cats}

Genetic Savings \& Clone, a biotechnology company that sold cloned pets, is to close due to lack of demand. Since the company opened in 2000 it has created five cloned cats butsold just two.

\section{NUMBER CRUNCH}

2-3 hurricanes were estimated to make landfall in the United States thishurricane season.

Ohurricanes have made landfall sofar.

\section{$\$ 6.5$ billion has been lost} by hedge fund Amaranth, which had bet on hurricanes hitting US oil depots and forcing up fuel prices.

\title{
Japan's new premier chases innovation
}

TOKYO

In a departure from tradition, Japan's new prime minister, Shinzo Abe, has appointed a vocal supporter of science, Kiyoshi Kurokawa, as his special adviser. The two men promise to reform dramatically Japan's rigid structures of scientific education, funding and decisionmaking, in order to boost technology and innovation in the country. But with hard details lacking, some observers are left wondering how much will really change.

Abe took over the premier job from Junichiro Koizumi in late September. He is expected to continue Koizumi's reforms of science policy, including making universities more competitive and increasing career opportunities for young researchers and women.

But in a surprise move, on 3 October Abe appointed Kurokawa, former president of the Science Council of Japan, as the cabinet's special adviser. Kurokawa is the first such adviser with a science background - his four predecessors were economic or legal experts. The motive seems to be a desire to boost the economy without falling back on tax cuts, which are unpopular in Japan. "I think the prime minister is aware that he needs a scientific adviser," says

SHINZO ABE, 52, PRIME MINISTER

A prince in the political world. His father was foreign minister, and his grandfather was Prime Minister Shinsuke Kishi. The first primeminister born after the Second World War, Abe held key positions in Koizumi's administration. But he is more hawkish than his predecessor, and aims to change, or at leastreinterpret, Japan's pacifist constitution to give the self-defence forces a more assertive role. He also promises to improve political relations with China and South Korea. Keen to revive the public education system, his catchphrases are "rechallenge" (giving people second chances to win good jobs) and, of course, "innovation".
Kurokawa. ${ }^{\alpha}$ To keep growing, we need innovation in science and technology that can totally change society, like the Industrial Revolution and the Internet."

Hiroyuki Abe, a member of the Japan Council for Science and Technology Policy and former president of Tohoku University, agrees, adding: "Kurokawa is the best choice because he's been calling for innovation and reforms at the top of academia."

A mong other things, Kurokawa will help to create Innovation 25, a plan to forecast what society's needs will be in 2025 , and suggest what research should be done in medicine, information technology and the environment to meet those needs. The push gives greater impetus to the direction Koizumi wanted to move in while he was in office. A team led by Kurokawa is expected to complete the plan by around June next year. It won't include any detailed policy recommendations, but could pave the way for increasing funding and overhauling the grant system, while reforming education and research systems to make them more flexible.

Ikuo Kabashima, professor of political science at the University of Tokyo, says that

KIYOSHI KUROKAWA, 70, SPECIAL ADVISER

A physician

specializing in kidney

medicine. Trained in

the United States, he practised and taught there for 15 years before serving as a professor at both the University of Tokyo and

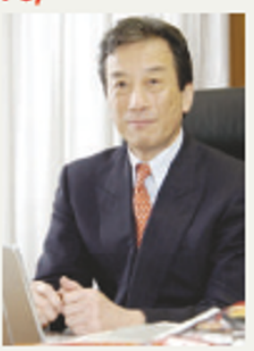

TokaiUniversity. Until

September he held the position of president of the Science Council of Japan, wherehe reformed its structure partly by increasing the number of femalemembers and by changing the way members are selected. Kurokawa has been outspoken in criticizing Japan's universities and researchers for boxing themselves into narrow research fields, and notconsidering international collaborations or how their research could be of wider use. 